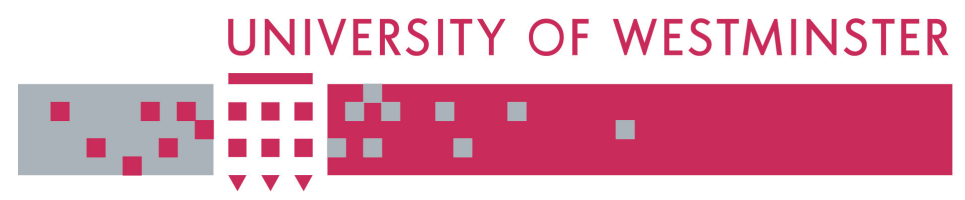

WestminsterResearch

http://www.wmin.ac.uk/westminsterresearch

\title{
Broadcasting historiography and historicality.
}

Paddy Scannell

School of Media, Arts and Design

This is a pre-copy-editing, author-produced PDF of an article accepted for publication in Screen following peer review. The definitive publisherauthenticated version of Scannell, Paddy (2004) Broadcasting historiography and historicality. Screen, 45 (2). pp. 130-141, is available from the publisher at:

http://screen.oxfordjournals.org/

The WestminsterResearch online digital archive at the University of Westminster aims to make the research output of the University available to a wider audience. Copyright and Moral Rights remain with the authors and/or copyright owners. Users are permitted to download and/or print one copy for non-commercial private study or research. Further distribution and any use of material from within this archive for profit-making enterprises or for commercial gain is strictly forbidden.

Whilst further distribution of specific materials from within this archive is forbidden, you may freely distribute the URL of WestminsterResearch.

(http://www.wmin.ac.uk/westminsterresearch).

In case of abuse or copyright appearing without permission e-mail wattsn@wmin.ac.uk. 


\section{Broadcasting historiography and historicality}

\section{Introduction}

By historiography I mean at least two things; the art or craft—-the practice—of writing history and, relatedly, the history of that craft, the history of History. ${ }^{1}$ Within the craft of history-now in the hands of academic practitioners - the history of media is a fairly well established sub-genre. In his recent magisterial review of the historiography of media James Curran manages to discover no less than seven different approaches to the history of modern media. ${ }^{2}$ The historicality of media, however, concerns their role in the unfolding of history itself. The subtitle of Dayan and Katz's well known work on media events is 'The live broadcasting of history'. That is a central concern of this article. But how are they connected: liveness, broadcasting and history? The common thread is time. Not the time of the universe (cosmological time), nor the time of the natural world (geological time; the theme of natural history), but the time of the being in the world of humanity. Historiography is, one way or another, the narrative of the presence in the world of human beings who are historical because they make history. ${ }^{4}$ The question then, more exactly, is who is the subject of history and what is history about?

I will consider three possible candidates as the subject of history: firstly, individuals; secondly, social institutions (the nation state; the institutions of religion, art and culture); third and last, humanity itself or, in other words, world history. As for the 'what' of history, it is about those kinds of event wherein history is made. No events, no history to put it as simply as possible. The uneventful is unhistorical. The task of historiography is to discover the story, and write the narrative of the historical event, thereby disclosing its significance. ${ }^{5}$ This is also the task of broadcast coverage of historic events, live and as they happen. In this article I engage with the possibility of different kinds of historical narrative and, linked to this, the differences between the written narratives of historiographers and the live-to-air narratives of broadcasters as they engage with history in its making.

By narrative I mean the act of narrating, of telling (in whatever medium) a story. A story, in its classic definition, has a beginning, middle and end. Its essential deictic components are time, place and person(s). In other words stories are always about situated someones, somewhere, sometime who either make things happen or suffer things happening to them. If nothing happens there is nothing to tell. Stories are intrinsically linked to events and have the same essential structure. Events are storyable because they start, go on and end. There are of course, as we shall see, open-ended story-events that have no resolution, but these are variants on the paradigm story structure with a beginning and end. The task of narrative (for historians or broadcasters) is to find the structure of the event-story under investigation and what it means,

\footnotetext{
${ }^{1}$ Ernst Breisach, Historiography (University of Chicago Press:1994). This standard work covers both aspects of historiography.

2 James Curran, 'Rival narratives of media history' in Media and Power (London: Routledge, 2002), 3-54.

${ }^{3}$ Daniel Dayan and Elihu Katz, Media Events (University of Harvard Press, 1992).

4 See Martin Heidegger, 'Temporality and historicality', Being and Time (Blackwell 1962), 424-455.

${ }^{5}$ Two succinct reviews of the much debated issues in the relationship between history, events and narrative are provided by Lawrence Stone, 'The revival of narrative: reflections on a new old history' in The Past and the Present Revisited (Routledge \& Kegan Paul: London, 1984), pp. 74-98, and Peter Burke, 'History of events and the revival of narrative' in New Perspectives on Historical Writing (Cambridge: Polity Press, 1991), pp.233-248. These deal with the topic largely in relation to the writings of historians. It has however become an issue of growing interest in philosophy, literary and social theory in the last forty years. See Geoffrey Roberts (ed.), The History and Narrative Reader (London: Routledge, 2001).
} 
thereby disclosing its significance. To narrate is not to chronicle. A chronology merely sets out what happened in its proper temporal sequence. A narrative recovers the significance and meaning of human actions embedded (embodied) in story-structures. ${ }^{6}$ The structure of stories is not, in the first place, a social, cultural or historical phenomenon. It is earlier than any of these. It is a foregiven, existential thing. The structure of stories is homologous with the structure of human life which begins, in each case, with the primary event of birth and goes on, through the life-span, towards the terminal event-horizon of death. This fundamental structure marks the 'real' conditions of human existence and is that upon which the social, the cultural and the historical articulate and express themselves. Individuals and human societies enact the stories of their existence. That is not to say that they narrate them. Indeed it is crucial question as to who can narrate such stories.

\section{Retrospective and prospective narratives}

In his fascinating notes on narrativity, ${ }^{7}$ the French psychoanalyst, Jean Laplanche, observes that it is closely connected to the way in which the human being temporalises himself, and to the idea of afterwardness. In psychoanalysis and psychopathology there is a tendency to privilege narrative in retrospect: life-histories, histories of illness and treatment, in accord with the clinical situation itself which is by definition retrospective. ${ }^{8}$ In the therapeutic situation, analyst and analysand work together by treating the enigmatic past as the obscure aetiology of the troubled now. This might well serve as a description, in a much wider sense, of the work of historiography which necessarily comes after the event and is therefore retrospective in character. The title of the most influential British history journal, Past and Present, underlines this. The temporality of written history moves on an axis from present to past and from past to present.

The act of writing comes after the event of necessity, because written texts are not produced at first go, 'just like that'. Writing (like making a movie) is a discontinuous process of stops and starts—of crossings out, revisions and corrections - in order to produce an edited, final 'clean' text that is free of spelling mistakes and grammatical errors while maintaining fluency and coherence. Writing is a slow process and itself takes time, a point famously underlined by Tristram Shandy as he tried to write the story of his own life. The more he wrote, the more time he took up and thus, as he found, he could never bring his life-story up to date. The novel stops - it doesn't come to an end-four years before Tristram's birth. The very act of writing it produced it as a receding narrative that moved away from its eponymous narrator even as he wrote. There is of course, a further time-lag, between the act of writing and the printing and distribution process. The tremendous technological developments in the 19th century produced a national daily press designed to overcome as far as possible the time-space constraints of the production circuit of writingprinting-distributing, but even news stories 'hot' from the press reach us hours after they have happened. In short, the medium of writing produces not merely narratives of the past, but the past as something that recedes from the present.

But with radio and television the time of the event and the time of its telling coincide. Both exist in the same phenomenal real time now. The phenomenal now is an aspect of the specific temporality of broadcasting whose most fundamental characteristic is its liveness. Liveness is not to be thought of simply as immediacy. We experience immediacy in the live-to-air coverage of events as they happen (a soccer match; 9/11) and in live-to-air news programmes. But the immediate present, in broadcasting is possible by virtue of, and exists in a dialectical relationship with, the historic present and the future present. All are conditional on, and indicative of, broadcasting's dailiness, the complex ways in which the existential, narrative arc of days is articulated in radio and television transmissions. The temporality of days has two

\footnotetext{
${ }^{6}$ This distinction owes much to the seminal essay by Georg Lukacs, 'Narrate or describe' in Writer and Critic (London Merlin Press, 1978), 111-148.

7 'An approach to the human individual which assigns a primordial importance to the manner in which he expresses his existence to himself in the form of a more or less coherent narrative'. Jean Laplanche, 'Narrativity and hermeneutics; some propositions', in New Formations (Number 48, Winter 2002-3), p. 26.

${ }^{8}$ Ibid. Emphasis as in the original.
} 
existential modes. 24/7 time produces a perpetual present (digital time produces a punctual now which knows no before or after: now it is 21.50 , now it is $21.51 \ldots$ ad infinitum). It elides the temporal specificity of days, their primordial existential structure and rhythm. Just as life begins, goes on and ends, so too do days. In all sorts of ways our ordinary language expresses the intimate connection between life and days; the days of our lives. The narrative arc of days—-morning, noon and night—corresponds with the narrative arc of our lives. The daily cycle of light and darkness, day and night, adumbrates life's existential conditions: birth, death and regeneration.

Broadcasting attends to the existential structure of days, thereby producing the phenomenal now in which past present and future encounter each other. This now (as distinct from the eternal, never ending now of digital time) is apparent in analogue time, which is told in relation to a past or a future (now it is ten to ten; now it is ten past ten). In analogue time the present is a dynamic temporality, a present-in-motion, that moves away from the past and towards the future. The phenomenal now gives history its possibility, since its essential structure is homologous with that of events and stories and is thereby, in principle, narratable. The future present shows up as such at the beginning of each day. Start-of-day news is not just at that time but for that time. In all sorts of ways a rolling three-hour news and discussion programme such as the aptly named Today (on BBC Radio 4) is concerned with the day ahead and all the upcoming and ongoing issues that will mark today as this day in particular. The routine, recurring time-checks, weather and traffic reports provide relevant data that allow listeners to orient themselves to and prepare for the day ahead. End-of-day news (BBC1, News at Ten) looks back on what was anticipated in start-of-day news. The historic present is retrospective, concerned with what has happened and what it means. It brings the events-of-the-day into the present in its live-to-air reports and interviews. It too exists in and for its own and particular time-of-day. It summarises, assesses and, where appropriate, brings closure to the now-passing day. The weather reports that immediately follow nightly news are oriented to tomorrow. News junkies, who switch to Newsnight (BBC 2: 10.30pm) after the news, know that they will get further discussion and comment on the events of the day. The programme always ends with a brief look at tomorrow's newspaper headline stories, thereby indicating closure and renewal. ${ }^{9}$ Thus routinely, day by day, broadcasting articulates and expresses each day in its prospective and retrospective character-its ontology of expectations, its assessments of whether they were met-in the live momentum of the phenomenal now from morning through to night.

\section{Events, narrative and history}

Dayan and Katz raised questions about the relationship between events, narrative and history. An event occurs when something happens in the world. They come in two varieties: the things that happen to us, and the things we make to happen. Dayan and Katz focus wholly on the latter class of events. The title of the French edition makes this clear: it is called La télévision cérémonielle and deals with festivals, celebrations and ceremonial occasions. The things that happen to us are a fundamental concern of news. They include disasters, a simplest taxonomy of which distinguishes between natural and human catastrophes. Natural disasters include earthquakes, volcanic eruptions, storms, hurricanes, disease, fire and flood and so on. Insofar as these impact on human life they are fateful events that are intrinsically historical. The great disasters of the past echo down through the millennia, from the great flood onwards, the great plague in $14^{\text {th }}$ century Europe, the great fire of London etc. They are, as a matter of routine, reported in today's news from all over the world.

Disasters, whether natural or human, are not meant to happen. They come upon us unexpectedly—out of a clear blue sky. Insofar as they were not in the first place meant and intended they appear strictly meaningless. We think of them as accidents, pointless tragedies. The task of disaster narratives in news is to find their meaning: what happened, who was affected, how many dead, how many alive, how is it being dealt with now, why did it happen, what can be done to prevent such a thing in future? In respect of human disasters the question why quickly becomes a matter of finding the fault. The questions scarcely arises in respect of natural disasters. Was it the fault of the weather? Or God? But the politics of blaming is intrinsic to human disasters and to finding their meaning. The day's coverage of September 11 is the most

\footnotetext{
${ }^{9}$ In the 1960 s the BBC had a five nights weekly magazine programme called Tonight which famously ended each transmission with the immortal exit line, 'The next Tonight will be tomorrow night'!
} 
extraordinary instance of the historical work routinely performed by broadcast news. When the first plane struck it was incomprehensible. When the second plane struck it was unbelievable. By the end of the day however newsrooms the world over had accounted for what had happened, shown what was being done for those most immediately caught up in what had happened; come up with plausible accounts of who had done it and forecast the political consequences. Past, present and future are routinely worked together in broadcast news, one of whose most basic functions, in moments of catastrophe, is to render meaningful and accountable that which at first appears meaningless and inexplicable.

In so doing, journalists act, not merely as chroniclers, but as historians of the present. Some professional historians have been deeply dismissive of this, rejecting what the Annales School called histoire événementielle as a superficial distraction from the real underlying task of historical analysis:

Instead of a history of events we should speak of a short time span, proportionate to individuals, to daily life, to our illusions, to our hasty awareness - above all the time of the chronicle and the journalist.... [S]ide by side with great and, so to speak, historic events, the chronicle or the daily paper offers us all the mediocre accidents of ordinary life: a fire, a railway crash, the price of wheat, a crime, a theatrical production, a flood... At first sight, the past seems to consist in just this mass of diverse facts...but this mass does not make up all of reality, all the depth of history on which scientific thought is free to work. Social science has almost what amounts to a horror of the event. ${ }^{10}$

Braudel shares that horror of the event, whose 'delusive smoke, fills the minds of contemporaries' but soon flickers and dies and leaves no lasting trace. The proper concerns of historians are not with the ephemera of daily life-for Braudel as for many intellectuals of the last century, the sphere of illusions and ideology — but with 'the depth' of history, slow time, what Braudel called the longue durée. The turn to a structural analysis of history, to the underlying determinants of historical actors and the events they enact, to their political and economic conditions was undoubtedly driven by the neglect of these determining factors in narrative histories. But it is not an either/or. That narrative history needs complementing by other kinds of history is by now beyond dispute. Yet events, whether natural (and suffered by us) or human (and created by us), remain at the heart of history's concerns since without them it is impossible to imagine what historiography might be about.

\section{Life histories}

Life, I have suggested, has a clear, obvious and well understood structure that is intimately linked to events and stories because they are all homologous. Life, event and narrative all have a beginning, middle and end. It is the end that is determinate, that throws the structure of our existence into sharp relief, that discloses it as a particular temporal structure. ${ }^{11}$ Death renders life meaningful. It is the foil that illuminates a life. It is only in death that the full narrative account of a life can be essayed since only in death are all possible future plot-lines closed down. The closure of death foreshadows narrative closure and gives the sense of an end to stories. It also gives us our sense of direction, since death is that towards which an individual life is pointed from the moment of birth. Birth and death are the first and last determinates of life which stretches between these two moments, moving away from one and towards the other. We call this the lifespan and the movement through it, the lifecycle: childhood, youth, adulthood, old age and death. The life cycle is a pre-determined sequence with a narrative arc of growth maturity and decline. It is irreversible. It is consequential. Death discloses a life as such and silently begins to reveal what it was and meant. The narrative of a life is an edited post-production.

We all understand that life is something which is, in each case, mine. It is my own, and no-one else's. I am, of course, in a very obvious way-at least in societies such as ours-the author of my life story. The choices I make along the way are determinate; they open up certain possibilities and foreclose on others.

\footnotetext{
${ }^{10}$ Fernand Braudel, 'History and the social sciences; the longue durée', On History (Weidenfeld and Nicolson: London, 1980), p. 28.

${ }^{11}$ On this theme see Heidegger, Being and Time, pp. 279-311.
} 
But I am not-nor could I be - the author of the narrative of my life. All life stories written in the first person are a form of special pleading, an egotism, an apologia, and as such must inevitably be taken by others with a pinch of salt however much fun they may be to read. ${ }^{12}$ It is not simply that the narrative of an individual only becomes completely and fully available after death. A narrative does not merely chronicle or describe a life. It must assess and evaluate it if it is to determine its significance, and that is never available to any of us. Was it a good life? Was I a good parent, husband, teacher, writer? Was I a good golfer? Was I good fun? I might like to believe that I was good in some at least if not all of these ways but even so I cannot lay claim to any of them as self-evaluations because in each and every case it is not for me, but for others to say. This is the impossibility of the first person point-of-view as a narrative device for life-histories. None of us is in a position to measure the impact of our life on others or, in other words, our historical significance. We lack an appropriate point of view. We cannot see ourselves as others do. The measure of the worth of individual existences does not lie with the individuals themselves. It is for others, for the world, to say.

\section{Institutional histories}

But a great deal of historiography concerns not individuals but human institutions of one sort or another. From a socio-political perspective we think of the great institutions of economic, political, religious and cultural life as power containers. Historians are concerned with their temporality, with how they endure through generations as devices that overcome the ruin of mortality. Such histories of course do not have the same narrative structure as life histories whose existential story structure ends in death. How then are institutions storyable? What is their story structure? The pioneering work of Christine Geraghty on the narrative structure of television drama serials is particularly illuminating in this connection. ${ }^{13}$ The first episode of a new soap, as she points out, presupposes an already existing world, and appears to cut into it as if it were already there, up and running. Moreover, while the subject of a life story is naturally enough an individual, the subject of soaps is a social world of some sort: the life world of a particular place or an institution. They are narratives of complex, structured social collectivities and are characterised by the interweaving of several different plotlines at any time. Geraghty is particularly illuminating on the temporality of soap operas; how they go on in time, their interconnected sense of their past and future as its shows up in any episode. Above all she shows that their structure is a device to generate a continuing unbroken coherent narrative that can, in principle, go on for ever. My question again is; who writes (who can write) such narratives?

Many years ago I saw a performance in London of Japanese Bunraku theatre. Bunraku is a puppet theatre but unlike marionettes which are attached to strings and manipulated by hidden puppeteers, the Bunraku puppets are held and manipulated by puppeteers who are unconcealed. The puppets are quite large, maybe three feet in height, and exquisitely made with perfect porcelain faces and gorgeous costumes. Each puppet has at least three handlers, dressed in black, their faces masked, but in full view of the audience. After a while you become aware of the extraordinary illusion this theatre produces. It seems as if-it is quite magical - that it is the puppet who manipulates its handlers and not the other way around. The puppet, it seems, imperiously puts out its hand, and the puppeteer obediently responds and places a fan in it which the puppet immediately snaps open. The puppeteers, it seems, are the servants of the puppet. And so it is with the fictional narratives of radio and television. The story scripts and enacts itself and its producers (scriptwriters, actors, production staff) are its servants. ${ }^{14}$ The Archers, to which I have listened for more

\footnotetext{
12 This is true at least for the autobiographies of public persons (politicians, celebrities etc) but not, perhaps, for those of unhistorical individuals who put on record what would otherwise be an unrecorded and unexamined existence.

${ }^{13}$ Christine Geraghty, 'The continuous serial-a definition', in Richard Dyer et al. (eds) Coronation Street, Television Monograph 13 (London: BFI), pp. 9-26.

14 Hobson's excellent study of Crossroads (a long running British soap in the 1980s and recently resurrected from the dead and restored to our television screens) is illuminating on the attitudes of actors and the production team to their 'puppet'. Dorothy Hobson, Crossroads. The Drama of a Soap Opera (London: Methuen, 1982).
} 
than twenty years, is half a century old: many of those who wrote, produced and acted in it are dead and forgotten, yet the story continues, unfolding day by day, quietly projecting into an indefinite future that has no necessary terminal point. Such narratives are peculiar to daily broadcast services and are formally indicative of their fundamental temporal structure.

The historical life of human institutions is like this too. They script and enact themselves and those who work in them are their servants. What can historians of institutions do, but cut into their history at a certain point, pursue it for a time and then cut out of it. David Cardiff and I did this in our history of the early BBC. ${ }^{15}$ We took a natural starting point- the beginning of a broadcast service in the UK-and a convenient end point (the outbreak of World War 2). Our narrative had many parallel and overlapping story-lines as we traced the development of news, talks, features, music, variety and outside broadcasts. And all these areas of output, plus others, are produced in order to serve the schedule which is the puppet that manipulates, that drives, the whole apparatus of broadcasting. It is the schedule that must at all times and for ever be maintained and fed with a never ending flow of diverse programme matter. The difference between our history of the BBC, and the work of those within the institution who supply the schedules is that our work is of necessity retrospective while theirs is of necessity prospective. No historian ever imagines that they could write a definitive history. History, as we all know full well, is always greater than, inevitably exceeds, our individual efforts because it is inexhaustible and keeps on going, projecting into a never ending future whereas mere mortal historiographers do not.

\section{World history}

My third candidate as the subject of history is the world itself. This history, for us in the West, is deeply saturated by the narrative of the world as told in the old and new testaments. This teleological narrative is one of original human alienation from God, the historical struggle for redemption, and for final reconciliation and reunion with the Creator. As and when that should come to pass, time ceases and history comes to an end. It is well understood that the Enlightenment rewrote this grand narrative ${ }^{16}$ as a secular, human-centred narrative of progress: the realisation of the kingdom of heaven on earth in the form of the truly good and just society. The greatest version of this narrative is Hegel's philosophy of history. ${ }^{17}$ For Hegel Geist is more than consciousness or mind. It is the spirit of humanity as a whole (past, present and future) whose historical destiny is not reconciliation with God but with itself. The world historical destiny of humanity is thus the working out of its own self-understanding. In achieving this humanity perfects itself and again history as struggle (or as John Ellis puts it as 'working through') ${ }^{18}$ comes to an end. Marx rewrote Hegel's grand narrative in terms of class struggle. The achievement of world socialism would mark the end of history as that struggle.

Hegel gave us the idea of world history and in the first half of the last century historians took up the challenge and attempted to write it. One of its last and most original practitioners was the Canadian economic historian, Harold Innis ${ }^{19}$ whose earlier work consisted of detailed studies of transport (the Canadian Pacific Railroad) and the staples of the $19^{\text {th }}$ century Canadian economy: fur, cod, timber and pulp. ${ }^{20}$ Innis came to see that what underpinned all his objects of enquiry were basic issues about the movement of goods and people, an economic and political geography determined by the available transport

\footnotetext{
${ }^{15}$ Paddy Scannell and David Cardiff, A Social History of British Broadcasting, 1922-1939 (Oxford: Blackwell, 1991).

${ }^{16}$ Jean Francois Lyotard has elegantly defined postmodernism as incredulity towards grand narratives. The Postmodern Condition: a Report on the Condition of Knowledge (Manchester: Manchester University

Press, 1986), pp.xxii-xxiv.

${ }^{17}$ On the impact of Hegel's Phenomenology of Mind [Geist] on historiography see Breisach, Historiography, 231-2, and especially 'The enigma of world history', pp. 395-403.

${ }^{18}$ John Ellis, Seeing Things (London: I.B Taurus, 2002), pp. 74-90.

19 Harold Innis, Empire and Communication (Oxford: Oxford University Press, 1950) and The Bias of Communication (Toronto: Toronto University Press 1964).

${ }^{20}$ The key work is Innis's magnificent study of The Fur Trade in Canada (Toronto: Toronto University Press, 1930/1999).
} 
and communication infrastructure. The infrastructure, he came to realise, was most fundamentally concerned with the management of time and space. Developments in transport and communication had a determinate effect on the scope of human praxis. Spengler and Toynbee had attempted to write world history in terms of the rise and fall of civilisations and religions. ${ }^{21}$ Innis rewrote it in terms of the management of time and space. The movement of Geist in history was replaced by the movement of goods and people.

This kind of historiography has long since fallen out of fashion and shows little sign of a comeback. Was it, is it, could it ever be a meaningful project? Whichever version of the narrative you prefer-the Bible, Hegel, Marx, Innis-it seems to me to have, at least, a robust story-structure. We understand well enough, today, that there was a time (the time of the universe, the time of the natural world) before the existence of humanity. We can well conceive a time after humanity. These are the familiar lineaments of the history of the human race. What lies between the beginning and the end of humanity is the history of its working through towards its end. But has it an end, an aim, a goal, a teleology? That of course is the crux. Who can say? Can we, the living, at any time? Historical truth is something to which we can, indeed, bear witness. But it not something we could ever possess for we ourselves - the living — are always and unavoidably in a relative position to historical truth; the unfolding story of the presence in the world of human beings. Every individual, every generation, contributes to the scripting and enactment of this single unfolding, eventful story, but it is an impossible narrative for none of us possesses a point of view from which it could be written. Formerly we understood it as God's narrative since to Him we attributed a sufficiently transcendental narrative point of view from which it could be told. But that understanding is no longer available to us. It is our fate today to be incredulous of grand narratives.

\section{The world-historical character of broadcasting}

I have pointed up the intrinsic connections between human existence, events, stories and narratives. Existence has a clear spatio-temporal story structure: a life is always a situated life; a someone somewhere sometime. It has a narrative arc of growth, maturity and decline. It is storyable insofar as it is eventful. Individuals, I have argued, author the story of their lives but cannot write its narrative. Institutions are human creations for the management of life in the long term. They are devices designed to transcend mortality. They work to the produce the world as always already there in advance, so that the living can always find themselves to be in a world of some sort. As such they are transcendental structures designed to segue from one generation to the next, surmounting the diremptions of death and maintaining the continuity of the world. Their narrative structure is like that of soap-operas; self-enacting, self-regenerating storystructures that transcend those who at any time write, produce and perform them. Such is human history, in its innumerable institutional instances and as a whole. Does the world have a history? I have tried to suggest that it does. The difficulty is that although we make this history, it cannot be written by any of us because there is no human vantage point from which to write it.

Three distinct orders of human time have been considered: the time of individuals, of social formations, of the world as a whole. These radically incommensurate historical temporalities, are all embedded in each other, but how are they connected? The times of individuals, of institutions and the world can only come together insofar as they are able to enter into a common, available time:

A standardised dating system, now universally acknowledged [and the establishment in the $19^{\text {th }}$ century of world standard time], provides for the appropriation of a unitary past, however much such "history" may be subject to contrasting interpretations. In addition, given the overall mapping of the globe that is today taken for granted, the unitary past is one which is worldwide; time and space are recombined to form a genuinely world-historical framework of action and experience. ${ }^{22}$

\footnotetext{
${ }^{21}$ Oswald Spengler The Decline of the West (1918) and Arnold Toynbee, Study of History (1934-9). For a succinct overview of both see Breisach, Historiography, pp. 397-400.

${ }^{22}$ Anthony Giddens, The Consequences of Modernity (Cambridge: Polity Press, 1990), pp. 20-21.
} 
As Giddens points out, the realignment of the calendar combined with the creation of universal standard time (GMT) establishes a common world time. Global transport and communication networks form interlocking grids that connect up the whole world. Broadcasting makes visible this world-in-common and day in day out reiterates as such. By broadcasting I mean not its manifestation any where in particular-not the services in the UK with which we are familiar, or French, or American broadcasting — but simply broadcasting as such: a global apparatus or network. At first broadcast services were local, then regional and national. They still appear as such, in situ, everywhere, but they are now globally interconnected. On major news stories, the same audio-visual data appears in news-programmes the world over. The fact that it is narrated and interpreted differently should not obscure the central point: the death of Diana and September $11^{\text {th }}$ were global stories that indicate the common world in which all of us live and in which, however obscurely, all our lives are interconnected. Such interconnectedness is manifest on such occasions and in the ceremonial events which are the theme of Dayan and Katz.

Broadcasting the world over, daily and routinely, is caught up in the enactment of history and at the same time in its interpretation and evaluation. It has well established devices and routines for narrating eventsin-the-world, live and as they happen anywhere. But the liveness of broadcasting is not simply a feature of certain kinds of live-to-air programmes. It is not the opposite of recorded programmes. ${ }^{23}$ Nor is it just an effect of technology. It is nothing to do with broadcasting in the first place. Liveness refers, after all, to being alive, the aliveness of our being. It is an existential phenomenon (the condition of our existence) that is reflexively redeemed by $20^{\text {th }}$ century electronic technologies whose unique communicative affordance ${ }^{24}$ is to give us, in unprecedented fashion, continuous daily access to the life and times of the world in which we live. This begins to disclose the world-historicality of radio and television which links individuals and the times of their lives to the times of the historical societies (or nation-states) in which they live and to the time of the world as a whole. These interconnected orders of time and their situational geographies ${ }^{25}$ are embedded in the daily schedules of broadcasting the world over. Through them we are gathered into the common world in which all of us encounter our worldly being-with-one-another as a relational totality of involvements.

Broadcasting makes sense of what is happening in the phenomenal now, without the wisdom of hindsight that is the privilege of historiography. Writing comes after the event. Electronic media are in the event. Writing moves on an axis between past and present. Broadcasting, situated always in the existential now (the nexus of the historic, immediate and future present), is structured in anticipation of what is to come. Historicality faces the future, whereas historiography faces the past. The historicality of humanity consists in its unique capacity to give itself a world and thereby to make, to create, its own history which is always the history of the world - that is, the known-and-available world as it is understood at any historical time by those who live in it. The historicality of broadcasting consists in its double role in the historical process. At one and the same time it contributes to the making of history while showing, recording and narrating it. Historiographers in the future - a century from now, say — will look back to broadcasting in our times in order to find out not only how we made our history but also how, through daily media, we told and understood it at the time.

[6092 words, including notes]

This paper was first presented at a one day workshop on 'Media times/historical times' at Goldsmith's College, Friday 25 April 2003. I am most grateful to Bill Schwartz and Annette Kuhn, for their helpful comments on the first draft of this article.

\footnotetext{
${ }^{23}$ Audio recordings capture and replay the liveness of the human voice as it speaks or sings.

${ }^{24}$ See Ian Hutchby, 'The communicative affordances of technological artefacts, Conversation and Technology (Cambridge: Polity Press, 2001), 13-33. Hutchby derives his concept from the work of J.J.Gibson on the psychology of perception: The Ecological Approach to Perception (London: Houghton Mifflin, 1979) and Reasons for Realism: Selected Essays (Hillsdale, NJ: Lawrence Erlbaum Associtaes, 1982).

${ }^{25}$ This phrase is taken from Joshua Meyrowitz, No Sense of Place (New York: Oxford University Press, 1985), p. 6.
} 